\title{
The Invention of Jewish Identity: Bible, Philo- sophy, and the Art of Translation, by Aaron W. Hughes
}

Lanham: Rowman \& Littlefield, 20 I I $\mid$ xiii +247 pages | ISBN: 978-I-4422-05 I6-I (hardback) \$49.95

In a debate over translation which seems to be polarised between meaning-based and formalist, this book

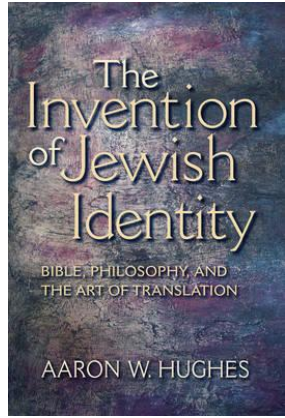
is a welcome contribution and I see it as an important supplement (in the non-Derridean kind of way) to Naomi Seidman's book Faithful Renderings (2006). While Seidman's book dealt with the Jewish relationship to Christianity (note the subtitle Jewish-Christian Difference and The Politics of Translation), Hughes's book remains-mostly-within the Jewish realm, which made me aware, more forcefully than Faithful Renderings, how different Jewish translation theory actually is, due to the roles of diasporic identity and its relationship to the Hebrew language. This is what The Invention of Jewish Identity is about. Given my own background in Protestant theology and its very static and simplified image of Judaism, being flung into discussions of Moses ibn Ezra and Maimonides on translating into silence, for example, proved to be a bit of an intellectual challenge. So while I didn't find it an easy read, I mostly enjoyed myself, with a few exceptions, such as the last chapter, to which I will return.

The book consists of six chapters and some concluding remarks. The first chapter provides the interpretive contexts and theoretical background for the discussions in the following five. Hughes outlines his view of translation as "a complex web tapestry of practical, historical, philosophical, and aesthetic processes" ( 5 ). Furthermore, he recaps various views on translation such as Friedrich Schleiermacher's and Walter Benjamin's, which provide him with the two necessary guides, namely the quotidian and the utopian, an en- 
counter, which translation seeks to bridge along with the past and the present, and the Hebraic and the non-Hebraic, while threatening to undermine the points of contact. Finally he defines a common ground for the individual Jewish translators under investigation in the book: namely that they all see something, silent traces, behind the language used in the Torah, and want to "unleash the eternal features of the Torah's nonlanguage that may have become embedded in the quotidian nature of human language" (I6). While I am less interested in Hughes's own reflections on translation, I find his analyses of the Jewish thinkers and their theoretical reflections fascinating and substantial.

The second chapter, on the forgetting of history and the memory of translation, is an analysis of Saadya Gaon (Egypt, 882-942) and Franz Rosenzweig (Germany, I886-1929), who also function as the bookends of the study. While the chapters all include the various encounters (past/present; quotidian/divine; Hebraic/non-Hebraic), this one focuses on the encounter of past and present as well as the particularities of linguistics and aesthetics. Both Saadya and Rosenzweig sought to renew Hebrew through their present languages: Arabic and German in order to retrieve the past and shape the future. The means of doing so were quite different. While Rosenzweig wanted to unfamiliarise Hebrew and German, Saadya emphasised the similarities between Hebrew and Arabic. This pattern of juxtaposing thinkers to bring out their similarities and differences is one Hughes follows throughout the book, and which works really well.

Chapter 3 is entitled "The translation of silence and the silence of translation: The fabric of metaphor" and focuses on two Andalusian Jewish thinkers, Moses ibn Ezra (ca. I055-I I 38 ) and Moses Maimonides (I I38-I 204). The catchphrase for this chapter is the Talmudic dictum, "Torah speaks in the language of humans," which is used to discuss the encounter between the quotidian and the utopian as well as the nature of human textuality (such as, e.g., metaphors) and the eternal, the initial silence. That was my favourite chapter, perhaps because it tapped into thoughts related to my present work on text and body, but also because it connected with one of my favourite novels, Chaim Potok's The Chosen, in which silence plays a major role.

The fourth chapter on the apologetics of translation deals with the superiority of Judaism and of the Torah through the construction of an ideal past. Jewish translation mobilises the effort to "claim" the intellectual and literary innovations of the world, which belonged to the Jews by virtue of possessing all wisdom through the gift of the Torah. This originally Jewish 
wisdom was subsequently stolen by the gentiles [ancient Greece, Muslim Spain, the Renaissance, the Weimar Republic], but could be re-absorbed through translation. This chapter deals primarily with Judah ben Yehiel Messer Leon (I 425-I495), who sought the "glimmer glowing from the veins of the Renaissance culture" in the Bible, and Martin Buber (I 878-I965), who was determined to break the connection between Judaism and the German context to emphasise Jewish difference. In fact, Buber's insistence on the Bible's non-rational and emotive order seems almost fashionable given the current interest in the emotions as object of historical research.

The fifth chapter, "Translation and Its Discontents," looks at the translations of Maimonides and Buber/Rosenzweig and the controversies arising from their efforts. Both translations attempted, in their own ways, to establish an authentic Jewish reading: Maimonides by restoring the language towards its prelapsarian state, and Buber/Rosenzweig by taking the Bible back to a purer linguistic (oral) moment. Both translations were criticised for creating an idolatrous (Maimonides) or artificial (Buber/Rosenzweig) text.

And then the final chapter: "Translation and Issues of Identity and Temporality." This is where I feel the book drags on a bit, and introduces new things towards the very end, which at this point I wasn't up for after all the new and fascinating stuff in the previous chapters. As far as the identity issues go, he recaps how the various individuals examined in the book relate to such issues, which is fine. But then he goes on to discussing the issue of temporality-and as a way of introducing his own take on the relationship between translation and temporality brings in Heidegger on the last five pages of the book. This seems to me like a last-minute brilliant idea he came up with in the shower. Furthermore, Naomi Seidman is relegated to these last pages as well. It just seems to be a last-minute add on, which is a shame. Personally, I would have preferred it if the book finished with the fifth chapter, and was then followed up with an article or another book, which deals with these things in a more substantial manner. Because presenting your own views on translation, utopia, and temporality after having dealt with the likes of Maimonides and Walter Benjamin makes it difficult not to disappoint your reader. But as far as those central four chapters go, I am all ears.

Christina Petterson Humboldt-Universität 